\title{
Correction to: Improving inbound logistic planning for large-scale real-world routing problems: a novel ant-colony simulation- based optimization
}

\author{
Giovanni Calabrò ${ }^{1}$, Vincenza Torrisi ${ }^{1 *}$, Giuseppe Inturri ${ }^{2}$ and Matteo Ignaccolo ${ }^{1}$
}

\section{Correction to: European Transport Research Review (2020) 12: 21 https://doi.org/10.1186/s12544-020-00409-7}

In the original publication of this article [1], a citation needs to be added in the section '1.1 The use of ant Colony optimization to solve the VRP'.

In the sentence 'In general, ACO is conceived to find the minimum cost paths within a network, so it presents several applications to routing and scheduling problems and is of particular interest in transport problems (Calabrò, G., Inturri, G., Le Pira, M., Pluchino, A., \& Ignaccolo, M.: Bridging the gap between weak-demand areas and public transport using an ant-colony simulation-based optimization. Forthcoming) [16].', the mentioned article in parenthesis has been published before the publication of the article [1], and should be cited as [4] in the article [1]. All the citation numbers after [3] should be revised as well.

[4] Calabrò, G., Inturri, G., Le Pira, M., Pluchino, A., \& Ignaccolo, M. (2020). Bridging the gap between weakdemand areas and public transport using an ant-colony simulation-based optimization. Transportation Research Procedia, 45, 234-241.

The original article has been updated.

The original article can be found online at https://doi.org/10.1186/s12544 020-00409-7

* Correspondence: vtorrisi@dica.unict.it; enza.torrisi@hotmail.it

'Department of Civil Engineering and Architecture, University of Catania,

Catania, Italy

Full list of author information is available at the end of the article
Author details

${ }^{1}$ Department of Civil Engineering and Architecture, University of Catania, Catania, Italy. ${ }^{2}$ Department of Electrical electronic and computer engineering, University of Catania, Catania, Italy.

Published online: 07 May 2020

Reference

1. Calabrò, et al. (2020). Improving inbound logistic planning for large-scale real-world routing problems: a novel ant-colony simulation-based optimization. European Transport Research Review, 12, 21.

\section{Springer Open}

(c) The Author(s). 2020 Open Access This article is licensed under a Creative Commons Attribution 4.0 International License, which permits use, sharing, adaptation, distribution and reproduction in any medium or format, as long as you give appropriate credit to the original author(s) and the source, provide a link to the Creative Commons licence, and indicate if changes were made. The images or other third party material in this article are included in the article's Creative Commons licence, unless indicated otherwise in a credit line to the material. If material is not included in the article's Creative Commons licence and your intended use is not permitted by statutory regulation or exceeds the permitted use, you will need to obtain permission directly from the copyright holder. To view a copy of this licence, visit http://creativecommons.org/licenses/by/4.0/. 